Jurnal Tanah dan Sumberdaya Lahan Vol 7 No 2 : 375-383, 2020

e-ISSN:2549-9793, doi: 10.21776/ub.jts1.2020.007.2.23

\title{
EVALUASI KESESUAIAN LAHAN DAN ANALISIS POTENSI PRODUKTIVITAS TANAMAN JAHE (Zingiber officinale Rosc.) DI KABUPATEN MALANG
}

\author{
Land Suitability Evaluation and Productivity Analysis of Ginger \\ (Zingiber officinale Rosc.) in Malang Regency
}

\author{
Iqbal Rizky Nugroho*, Syahrul Kurniawan, Aditya Nugraha Putra \\ Jurusan Tanah, Fakultas Pertanian, Universitas Brawijaya, Jl. Veteran 1, Malang, Jawa Timur 65145 \\ *Penulis korespondensi: irizzky1997@gmail.com
}

\begin{abstract}
Suitable land is needed to support the growth of the ginger plant to increase its productivity. Climate, soil physics, soil chemistry, and land data information are needed for land suitability assessment. Land suitability evaluation technology is used to identify suitable land to grow optimally. This study aimed to map the ginger suitability in Malang district, analyze the limiting factors that most influence the growth of ginger, and analyze the relationship between land suitability class and ginger productivity in Malang district. The study was conducted using the survey method active field survey. The method for determining land suitability criteria used criteria developed by the Ministry of Agriculture of Indonesia. The data obtained were analyzed using correlation and regression. The results showed that the level of slope did not affect productivity. The research area, which is located in Karangploso, Singosari, Jabung, Pagak, and Kalipare Districts, has a grade of land suitability S3 (marginally suitable). Based on the results of the study, the level of slope does not affect productivity, the research areas which are located in Karangploso district, Singosari, Jabung, Pagak and Kalipare has a grade of land suitability S3 (Marginally Suitable). The characteristics of the land that most influenced the productivity of ginger according to the sequence were available- $\mathrm{P}$, organic-C, CEC, and exchangeable $\mathrm{Ca}$ with the equation of $\mathrm{y}=3.292+(0 .-219) \mathrm{X} 1+0.333 \mathrm{X} 2+0.335 \mathrm{X} 3+0.348 \mathrm{X} 4$ and $\mathrm{R}^{2}=0,695$. Land suitability class had a strong relationship with ginger plant productivity; the value of the correlation coefficient $(\mathrm{r})$ was 0.766 .
\end{abstract}

Keywords: ginger productivity, land characteristic, land suitability, potential productivity

\section{Pendahuluan}

Jahe merupakan salah satu jenis komoditas tanaman obat-obatan yang dapat dimanfaatkan sebagai bahan olahan ramuan, rempah-rempah atau obat. Jahe yang biasa dikonsumsi di Indonesia terdapat 3 jenis yaitu jahe gajah (Zingiber officinale Rosc. var. officinale), jahe emprit (Zingiber officinale Rosc. var. rubrum) dan jahe merah (Zingiber officinale Rosc. var. amarum) (Rosiana et al., 2005). Menurut Badan Pusat Statistik (2017), produksi jahe di Indonesia dari tahun 2012 sampai tahun 2016 mengalami peningkatan sebesar 197\% (225,804 t ha-1), namun pada tahun 2017 produksi jahe mengalami penurunan sebesar 36,7\% $(124,775 \mathrm{t}$ $h^{-1}{ }^{-1}$. Penurunan produksi diduga terjadi karena berkaitan dengan adanya penurunan kualitas dan luas lahan area tanaman jahe yang terjadi pada tahun 2016 sampai tahun 2017 mencapai $18,37 \%$ (2.375,73 ha). Selama periode 20112015, perkembangan tingkat konsumsi jahe di Indonesia cenderung naik sebesar 21,95\%. Konsumsi jahe pada tahun 2014 sebesar 167.687 ton dan meningkat menjadi 282.025 ton pada tahun 2015 (Badan Pusat Statistik, 2016). Seiring meningkatnya permintaan jahe menyebabkan perlunya lahan pertanian yang subur dan potensial untuk tanaman jahe, serta adanya 
persaingan terhadap penggunaan lahan antara sektor pertanian dan non pertanian, sehingga memerlukan solusi yang tepat dalam upaya mengoptimalkan penggunaan lahan secara berkelanjutan. Manajemen lahan yang diterapkan secara intensif memerlukan biaya yang cukup besar, sehingga diperlukan teknologi yang tepat untuk dapat mengatasi masalah tersebut. Evaluasi kesesuaian lahan merupakan teknologi yang diharapkan mampu untuk meningkatkan produktivitas. Evaluasi kesesuaian lahan adalah proses penilaian potensi atau penggambaran tingkat kecocokan sebidang lahan untuk suatu penggunaan tertentu secara spesifik. Oleh karena itu, pentingnya dilakukan penelitian ini agar dapat memberikan informasi yang akurat mengenai evaluasi kesesuaian lahan sehingga dapat diterapkan manajemen lahan yang optimal untuk meningkatkan produktivitas jahe dan dapat menurunkan biaya produksi.

\section{Bahan dan Metode}

\section{Tempat dan waktu penelitian}

Penentuan lokasi penelitian dilakukan secara acak di Kabupaten Malang. Penelitian dilakukan di 5 Kecamatan di Kabupaten Malang yaitu Kecamatan Karangploso, Kecamatan Singosari, Kecamatan Jabung, Kecamatan Pagak, dan Kecamatan Kalipare. Kegiatan penyiapan dan pengolahan data peta dilaksanakan di Laboratorium PSISDL, analisis kimia tanah dilaksanakan di Laboratorium Kimia, dan analisis tekstur dilakukan di Laboratorium Fisika Tanah Jurusan Tanah, Fakultas Pertanian, Universitas Brawijaya, Malang, Jawa Timur. Waktu penelitian dilaksanakan mulai bulan Juli 2018 hingga Januari 2020. Alat yang digunakan adalah Software ArcGIS 10.3, software Global Mapper, Avenza Map, software Microsoft Excel, software SPSS v.22. Bahan yang digunakan adalah DEM (Digital Elevation Model) $12,5 \mathrm{~m}$, peta geologi, data curah hujan BPDAS 2006-2016, shapefile administrasi BPS 2013, air.

\section{Metode}

Metode yang digunakan adalah metode survei active field survey. Data produktivitas lahan diperoleh melalui wawancara. Metode yang digunakan untuk penentuan kriteria kesesuaian lahan menggunakan pendekatan mencocokkan (matching) (Djaenudin et al., 2011). Penentuan titik lokasi pengamatan menggunakan peta SPL (Satuan Penggunaan Lahan) hasil dari kegiatan overlay peta formasi geologi, relief, dan penggunaan lahan berupa tegalan dan kebun. Berdasarkan pengamatan peta SPL, didapatkan sebanyak 5 SPL yang akan dijadikan lokasi pengamatan. SPL akan disajikan pada Tabel 1. Titik pengamatan yang ditentukan berdasarkan peta SPL didapatkan sebanyak 22 titik. Karakteristik titik pengamatan disajikan pada Tabel 2. Titik 1a, 1b, 2a, 2b, 3a, dan 3b berada di Kecamatan Karangploso, 1c, 1d, 4a, 4b, 2c, 2d, 5a, 5b, 3c, dan 3d berada di Kecamatan Singosari, 4c dan 4d berada di Kecamatan Jabung, 5c dan 5d berada di Kecamatan Pagak, $5 e$ dan $5 f$ berada di Kecamatan Kalipare.

Tabel 1. Karakteristik Satuan Penggunaan Lahan.

\begin{tabular}{ccc}
\hline SPL & Keterangan & $\begin{array}{c}\text { Daerah } \\
\text { Pengamatan }\end{array}$ \\
\hline \multirow{2}{*}{1} & Qvaw, 8-15\%, & Singosari + \\
& Tegalan & Karangploso \\
2 & Qvaw,15- & Singosari + \\
& $25 \%$, Tegalan & Karangploso \\
3 & Qvaw,15- & Singosari + \\
& $25 \%$, Kebun & Karangploso \\
4 & Qvtm,3- & Singosari + Jabung \\
& $8 \%$, Tegalan & Qingosari + Pagak \\
5 & Qvtm,8- & Singalian \\
& $15 \%$, Tegalan & + Kalipare \\
\hline
\end{tabular}

Pengamatan fisiografi lahan dilakukan dengan menilai kondisi disekitar lahan berdasarkan form (lembar nilai di lapangan) yang telah dibuat untuk kebutuhan di lapangan. Pengamatan morfologi tanah dilakukan dengan cara pembuatan minipit sedalam $50 \mathrm{~cm}$ untuk mengetahui batas-batas horizon dan dilanjutkan pengeboran sedalam $20 \mathrm{~cm}$ untuk mengetahui lapisan tanah di bawahnya. Pengambilan sampel tanah dilakukan pada kedalaman 0-40 cm secara komposit. Sampel tanah yang didapatkan dilakukan analisis laboratorium berupa analisis tekstur, $\mathrm{pH}, \mathrm{C}$-organik, P-tersedia, $\mathrm{N}_{\text {total }}, \mathrm{K}_{\mathrm{dd}}$, $\mathrm{Na}_{\mathrm{dd}}, \mathrm{Ca}_{\mathrm{dd}}, \mathrm{Mg}_{\mathrm{dd}}$, KTK dan Kejenuhan Basa. Data yang diperoleh dari hasil kegiatan di lapangan dan di laboratorium kemudian dilakukan analisis korelasi untuk mengetahui 
seberapa besar hubungan parameter dengan produktivitas dan analisis regresi untuk mengetahui seberapa besar pengaruh parameter dengan produktivitas. Data yang dilakukan analisis hanya titik pengamatan yang memiliki data produktivitas.

Tabel 2. Titik pengamatan.

\begin{tabular}{cc}
\hline Titik Pengamatan & Unit Lahan \\
\hline 1a, 1b, 1c, dan 1d & Qvaw, 8-15\%, \\
& Tegalan \\
2a, 2b, 2c, dan 2d & Qvaw,15- \\
& $25 \%$,Tegalan \\
3a, 3b, 3c, dan 3d & Qvaw, 15- \\
& $25 \%$, Kebun \\
4a, 4b, 4c, dan 4d & Qvtm,3-8\%,Tegalan \\
$5 \mathrm{a}, 5 \mathrm{~b}, 5 \mathrm{c}, 5 \mathrm{~d}, 5 \mathrm{e}$, dan & Qvtm,8- \\
$5 \mathrm{f}$ & $15 \%$, Tegalan \\
\hline
\end{tabular}

Terdapat 14 Titik pengamatan yang memiliki data produktivitas dan 8 titik lainnya tidak terdapat data produktivitas. Penilaian keeratan hubungan dengan cara membandingkan antara r-hitung dengan r-tabel, apabila r-hitung lebih besar dibandingkan dengan r-tabel maka kedua variabel memiliki keeratan hubungan yang kuat, sebaliknya jika r-hitung memiliki nilai yang lebih rendah dibandingkan dengan r-tabel, maka kedua variabel tidak memiliki hubungan keeratan yang kuat. Setelah dilakukan uji korelasi, selanjutnya parameter yang memiliki keeratan hubungan yang kuat dilakukan uji regresi linier menggunakan metode stepwise. Hasil dari uji regresi menghasilkan formula persamaan hubungan dari kualitas dan karakteristik lahan dengan produktivitas jahe. Berdasarkan formula persamaan tersebut, kemudian dilakukan penarikan batas (Boundary line) yang dilakukan di Microsoft Excell. Penarikan batas dimaksudkan untuk menentukan batas kelas produktivitas jahe.

\section{Hasil dan Pembahasan \\ Karakteristik lahan lokasi penelitian}

Karakteristik lahan yang diamati yaitu temperatur (tc) meliputi temperatur rerata, ketersediaan air (wa) meliputi curah hujan, ketersediaan oksigen (oa) meliputi drainase, media perakaran (rc) meliputi tekstur dan kedalaman tanah, retensi hara (nr) meliputi KTK, KB, pH, dan C-organik, bahaya erosi (eh) meliputi lereng dan bahaya erosi. Penilaian seluruh karakteristik lahan disajikan pada Gambar 1.

\section{Kelas kesesuaian lahan aktual jahe}

Penentuan Kelas Kesesuaian Lahan jahe menggunakan metode membandingkan (matching) antara hasil analisis laboratorium dan pengamatan di lapangan dengan kriteria kesesuaian lahan tanaman jahe menurut Djaeundin et al. (2011). Hasil analisis kelas kesesuaian lahan aktual tanaman jahe disajikan pada Tabel 3 dan Gambar 2.

Tabel 3. Kelas kesesuaian lahan aktual.

\begin{tabular}{cccc}
\hline Titik pengamatan & KKL & Sub-KKL & Faktor Pembatas \\
\hline 1a & S3 & S3-wa,nr & Curah hujan, kejenuhan basa, dan pH \\
1b & S3 & S3-wa,nr & Curah hujan, kejenuhan basa, dan pH \\
2c & S3 & S3-wa,nr & Curah hujan dan pH \\
2d & S3 & S3-wa,nr & Curah hujan, kejenuhan basa, dan pH \\
3a & S3 & S3-eh,wa,nr & Lereng, curah hujan, dan kejenuhan basa \\
3b & S3 & S3-eh,wa,nr & Lereng, curah hujan, dan kejenuhan basa \\
3c & S3 & S3-eh,wa,nr & Lereng, curah hujan, dan pH \\
3d & S3 & S3-eh,wa,nr & Lereng, curah hujan, dan pH \\
4a & S3 & S3-wa,nr & Curah hujan, kejenuhan basa, dan pH \\
4b & S3 & S3-wa,nr & Curah hujan, kejenuhan basa, dan pH \\
4c & S3 & S3-wa,nr & Curah hujan, kejenuhan basa, dan pH \\
4d & S3 & S3-wa,nr & Curah hujan, kejenuhan basa, dan pH \\
5c & S3 & S3-wa,nr & Curah hujan, kejenuhan basa, dan pH \\
5d & S3 & S3-wa,nr & Curah hujan dan pH \\
\hline
\end{tabular}


Jurnal Tanah dan Sumberdaya Lahan Vol 7 No 2 : 375-383, 2020

e-ISSN:2549-9793, doi: 10.21776/ub.jts1.2020.007.2.23
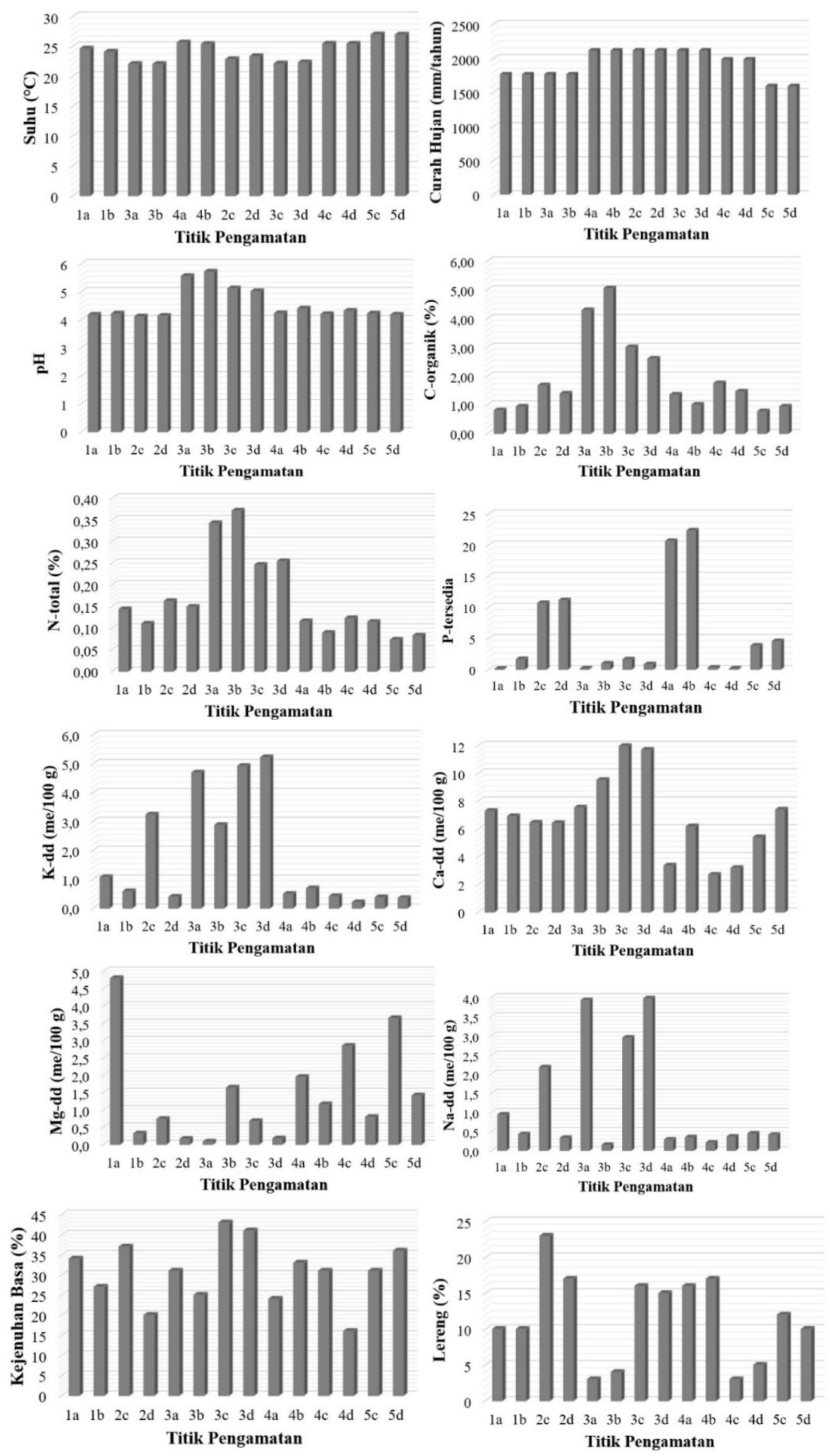

Gambar 1. Grafik berbagai karakteristik lahan di titik pengamatan. 


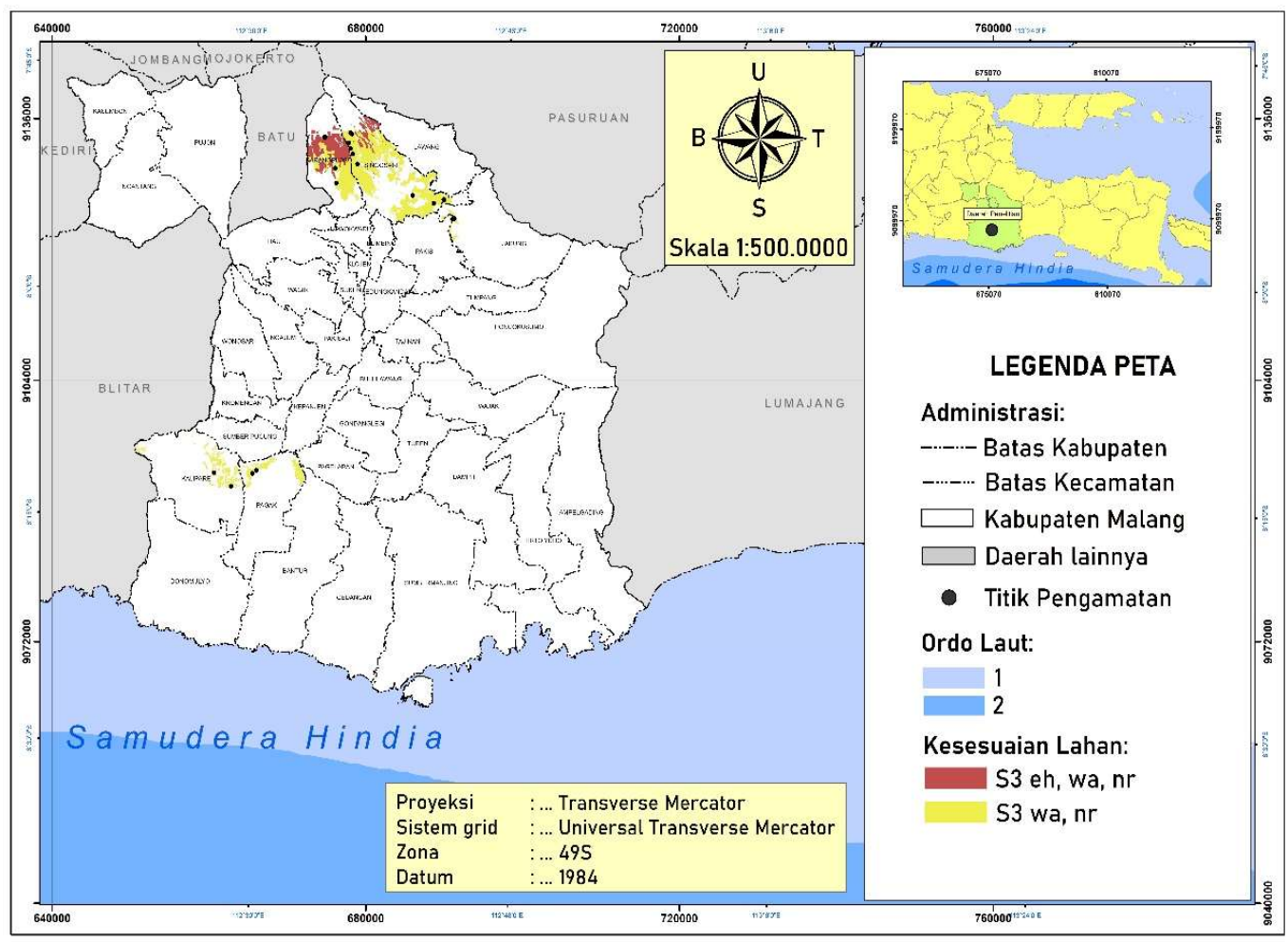

Gambar 2. Peta kelas kesesuaian lahan aktual.

Hasil analisis menunjukkan bahwa kelas kesesuaian lahan di seluruh titik pengamatan tergolong kedalam kelas S3 (Sesuai Marginal). Kelas kesesuaian lahan S3 adalah lahan yang mempunyai pembatas yang sangat berat untuk mempertahankan tingkat pengelolaan yang harus dilakukan. Faktor pembatas akan mengurangi produktivitas dan keuntungan (FAO, 1976). Faktor-faktor pembatas yang didapat di seluruh titik pengamatan yaitu lereng, curah hujan, kejenuhan basa, dan pH. Faktor pembatas lereng berada di titik pengamatan $3 a$, 3b, 3c, dan 3d. Pada titik tersebut, tingkat kelerengan mencapai 16 hingga 23\%. Faktor pembatas curah hujan terjadi di semua titik pengamatan dengan nilai curah hujan sebesar 1415 hingga $1794 \mathrm{~mm}$ selama masa tanam. Faktor pembatas kejenuhan basa terjadi di hampir semua titik terkecuali pada titik 2c, 3c, 3d, dan 5d. Pada titik yang mempunyai faktor pembatas kejenuhan basa berada pada daerah yang memilikinilai kejenuhan basa sebesar 11 hingga $33 \%$. Faktor pembatas $\mathrm{pH}$ terjadi di hampir semua titik pengamatan terkecuali $3 \mathrm{a}$ dan 3b. Titik pengamatan yang memiliki faktor pembatas $\mathrm{pH}$ memiliki nilai $\mathrm{pH}$ sebesar 4,02 hingga 5,12.

\section{Keselarasan hasil kesesuaian lahan dengan modifikasi}

Hasil kelas kesesuaian lahan modifikasi dilakukan dengan cara melakukan penarikan batas (Boundary line). Kriteria karakteristik lahan baru yang didapat adalah P-tersedia, C-organik, KTK, kelerengan, dan Ca-dd. Setelah dilakukan penarikan batas didapatkan hasil kriteria lahan untuk tanaman jahe hasil modifikasi kriteria menurut Djaenudin et al. (2011). Keselarasan antara kesesuaian lahan dengan modifikasi disajikan pada Tabel 4. Berdasarkan kriteria modifikasi, seluruh titik pengamatan memiliki kelas kesesuaian lahan yang sama (tidak berubah) dengan kriteria kesesuaian lahan menurut Djaenudin et al. (2011). Hasil tersebut menunjukkan bahwa kelas kesesuaian lahan modifikasi tidak merubah kelas kesesuaian lahan (selaras) dari kriteria Djaenudin et al. (2011). 


\section{Hubungan antara kelas kesesuaian lahan dengan produktivitas}

Hasil mencocokkan yang dilakukan antara kriteria kelas kesesuaian lahan (Djaenudin et al., 2011) dengan hasil modifikasi menunjukkan hasil kelas kesesuaian lahan yang homogen, maka berarti dengan dilakukannya penarikan batas (boundary line) tidak merubah kelas kesesuaian lahan namun menambah beberapa karakteristik lahan baru. Karakteristik lahan baru yang ditambahkan yaitu karakteristik lahan yang berpengaruh terhadap tingkat produktivitas lahan. Karakteristik lahan yang berpengaruh adalah P-tersedia, C-organik, KTK, dan Ca-dd. Setiap kelas kesesuaian lahan memiliki potensi produktivitas yang bervariasi. Menurut FAO (1976) potensi produktivitas tingkat kelas kesesuaian lahan S1 adalah sebesar $80 \%$ dari hasil maksimum, S2 sebesar 60\%, S3 sebesar $40 \%$, dan $\mathrm{N}$ sebesar $<40 \%$. Acuan hasil produktivitas maksimum tanaman jahe menurut (Ditjenbun (2004) sebesar 5-6 t ha-1. Berdasarkan penentuan kelas potensi produktivitas menurut FAO maka didapatkan hasil bahwa untuk kelas kesesuaian lahan S1 memiliki potensi produktivitas jahe sebesar 4,8 t $\mathrm{ha}^{-1}$, kelas kesesuaian lahan S2 memiliki potensi produktivitas sebesar 3,6 t ha-1, kelas kesesuaian lahan S3 memiliki potensi produktivitas sebesar 2,4 t ha ${ }^{-1}$, dan kelas kesesuaian lahan $\mathrm{N}$ memiliki potensi produktivitas sebesar $<2,4 \mathrm{t} \mathrm{ha-1}$. Hubungan antara kelas kesesuaian lahan dengan potensi produktivitas disajikan pada Tabel 5 . Berdasarkan hasil tersebut maka dapat diketahui hubungan antara kelas kesesuaian modifikasi dengan potensi produktivitas memiliki hubungan keeratan yang kuat. Titik 1a, 1b, 2c, 2d, 3a, 3b, 3c, 3d, 4c, 4d, 5c, dan 5d didapatkan hasil yang sesuai dengan kelas potensi produktivitas yaitu S3 (40 - 60\%) dan 4a dan 4b memiliki potensi produksi yang tidak sesuai dengan kelas potensi produktivitas yaitu $\mathrm{N}$ ( > 40\%). Kelas kesesuaian lahan dengan produktivitas mempunyai hubungan yang kuat, hal tersebut dapat diketahui dengan koefisien korelasi (r) sebesar 0,766.

\section{Hubungan C-organik dengan produktivitas}

Berdasarkan hasil uji korelasi hubungan antara C-organik dengan produktivitas jahe menunjukkan bahwa C-organik memiliki keeratan yang kuat dengan produktivitas, nilai koefisien korelasi (r) yang didapat sebesar 0,608. Hasil korelasi menunjukkan nilai yang positif, maka dapat diasumsikan bahwa setiap kenaikan C-organik akan diikuti dengan meningkatnya produktivitas jahe. Hubungan linier pada persamaan $y=0,186 x+2,532$ memiliki arti bahwa setiap kenaikan 1\% C-organik dapat meningkatkan produktivitas jahe $0,186 \mathrm{t} \mathrm{ha}^{-1}$.

Tabel 4. Keselarasan kesesuaian lahan dengan modifikasi.

\begin{tabular}{|c|c|c|}
\hline Titik pengamatan & $\begin{array}{c}\text { KKL } \\
\text { Djaenudin et al. (2011) }\end{array}$ & $\begin{array}{c}\text { KKL } \\
\text { (Boundary line) }\end{array}$ \\
\hline $1 \mathrm{a}$ & S3 (Curah hujan, $\mathrm{KB}$, dan $\mathrm{pH}$ ) & S3 (Curah hujan, KB, dan $\mathrm{pH}$ ) \\
\hline $1 \mathrm{~b}$ & $\mathrm{~S} 3$ (Curah hujan, $\mathrm{KB}$, dan $\mathrm{pH}$ ) & $\mathrm{S} 3$ (Curah hujan, $\mathrm{KB}$, dan $\mathrm{pH}$ ) \\
\hline $2 c$ & S3 (Lereng, curah hujan, dan KB) & S3 (Lereng, curah hujan, dan KB) \\
\hline $2 \mathrm{~d}$ & S3 (Lereng, curah hujan, dan KB) & S3 (Lereng, curah hujan, dan KB) \\
\hline $3 a$ & S3 (Curah hujan, KB, dan pH) & S3 (Curah hujan, KB, dan pH) \\
\hline $3 \mathrm{~b}$ & S3 (Curah hujan, $\mathrm{KB}$, dan $\mathrm{pH}$ ) & $\mathrm{S} 3$ (Curah hujan, $\mathrm{KB}$, dan $\mathrm{pH}$ ) \\
\hline $3 c$ & S3 (Curah hujan dan $\mathrm{pH}$ ) & S3 (Curah hujan dan $\mathrm{pH}$ ) \\
\hline $3 d$ & S3 (Curah hujan, KB dan $\mathrm{pH}$ ) & S3 (Curah hujan, KB dan $\mathrm{pH}$ ) \\
\hline $4 \mathrm{a}$ & S3 (Lereng, curah hujan, dan $\mathrm{pH}$ ) & S3 (Lereng, curah hujan, dan pH) \\
\hline $4 \mathrm{~b}$ & S3 (Lereng, curah hujan, dan $\mathrm{pH}$ ) & S3 (Lereng, curah hujan, dan $\mathrm{pH}$ ) \\
\hline $4 c$ & $\mathrm{~S} 3$ (Curah hujan, $\mathrm{KB}$, dan $\mathrm{pH}$ ) & S3 (Curah hujan, KB, dan $\mathrm{pH}$ ) \\
\hline $4 d$ & $\mathrm{~S} 3$ (Curah hujan, $\mathrm{KB}$, dan $\mathrm{pH}$ ) & $\mathrm{S} 3$ (Curah hujan, $\mathrm{KB}$, dan $\mathrm{pH}$ ) \\
\hline $5 c$ & $\mathrm{~S} 3$ (Curah hujan, $\mathrm{KB}$, dan $\mathrm{pH}$ ) & S3 (Curah hujan, KB, dan $\mathrm{pH}$ ) \\
\hline $5 d$ & S3 (Curah hujan dan pH) & S3 (Curah hujan dan $\mathrm{pH}$ ) \\
\hline
\end{tabular}


Jurnal Tanah dan Sumberdaya Lahan Vol 7 No 2 : 375-383, 2020

e-ISSN:2549-9793, doi: 10.21776/ub.jts1.2020.007.2.23

Tabel 5. Hubungan antara kelas kesesuaian lahan dengan potensi produktivitas.

\begin{tabular}{|c|c|c|c|c|c|}
\hline $\begin{array}{c}\text { Titik } \\
\text { Pengamatan }\end{array}$ & $\begin{array}{c}\text { KKL } \\
\text { Djaenudin } \\
\text { et al. } \\
(2011)\end{array}$ & $\begin{array}{c}\text { KKL } \\
\text { (Boundary } \\
\text { line) }\end{array}$ & $\begin{array}{c}\text { Produktivitas } \\
\text { Lahan } \\
\text { Aktual } \\
\left(\mathrm{t} \mathrm{ha}^{-1}\right)\end{array}$ & $\begin{array}{c}\text { Presentase } \\
(\%)\end{array}$ & $\begin{array}{c}\text { Potensi } \\
\text { Produktivitas } \\
(\text { FAO }) \\
\left(\mathrm{t} \mathrm{ha}^{-1}\right)\end{array}$ \\
\hline $1 \mathrm{a}$ & S3 & S3 & 2,8 & 46,6 & S3 \\
\hline $1 \mathrm{~b}$ & S3 & S3 & 3 & 50 & S3 \\
\hline $2 c$ & S3 & S3 & 2,54 & 42,3 & S3 \\
\hline $2 d$ & S3 & S3 & 2,54 & 42,3 & S3 \\
\hline $3 a$ & S3 & S3 & 3,2 & 53,3 & S3 \\
\hline $3 b$ & S3 & S3 & 3,5 & 58,3 & S3 \\
\hline $3 c$ & S3 & S3 & 3,29 & 54,8 & S3 \\
\hline $3 \mathrm{~d}$ & S3 & S3 & 3,23 & 53,8 & S3 \\
\hline $4 \mathrm{a}$ & S3 & S3 & 2,1 & 35 & $\mathrm{~N}$ \\
\hline $4 \mathrm{~b}$ & S3 & S3 & 2,2 & 36,6 & $\mathrm{~N}$ \\
\hline $4 c$ & S3 & S3 & 3 & 50 & S3 \\
\hline $4 d$ & S3 & S3 & 3,05 & 50,8 & S3 \\
\hline $5 c$ & S3 & S3 & 3 & 50 & S3 \\
\hline $5 \mathrm{~d}$ & S3 & S3 & 3 & 50 & S3 \\
\hline
\end{tabular}

Keterangan: Garis berwarna oranye menunjukkan hasil hubungan yang tidak sesuai antara KKL dengan potensi produktivitas.

Nilai $R^{2}=0,370$ menunjukkan bahwa $37 \%$ peningkatan yang terjadi terhadap C-organik akan diikuti oleh peningkatan produktivitas jahe dan sisanya dipengaruhi oleh faktor lain. Corganik tanah menunjukkan indikator tinggi rendahnya kandungan bahan organik yang ada di dalam tanah, hal ini didukung oleh pernyataan Susanto (2005) yang menyatakan bahwa kandungan bahan organik pada masing-masing horizon merupakan petunjuk besarnya akumulasi bahan organik dalam keadaan lingkungan yang berbeda. Berdasarkan hasil penarikan garis batas, dapat ditentukan batas kelas C-organik antara kelas S3 dengan S2 adalah 5,74\%, untuk batas kelas S2 dengan S1 adalah 12,1\%, batas kelas $\mathrm{N}$ dengan S3 tidak dapat diketahui karena kurangnya sebaran data yang ada.

\section{Hubungan P-tersedia dengan produktivitas}

Berdasarkan hasil uji korelasi hubungan antara P-tersedia dengan produktivitas jahe menunjukkan bahwa P-tersedia memiliki keeratan yang kuat dengan produktivitas, nilai koefisien korelasi (r) yang didapat sebesar 0,646. Hasil korelasi antara produktivitas dengan P-tersedia menunjukkan nilai yang negatif, artinya setiap penurunan yang terjadi terhadap P-tersedia, maka akan diikuti dengan meningkatnya produktivitas jahe. Hubungan linier pada persamaan $y=-0,048 x+3,163$ memiliki arti bahwa setiap kenaikan 1 ppm Ptersedia dapat meningkatkan produktivitas jahe sebesar $0,048 \mathrm{tha}^{-1}$, namun pada hasil ini nilai Ptersedia berbanding terbalik dengan pernyataan yang disampaikan menurut Rosita et al. (2006) yang menyatakan bahwa untuk menghasilkan pertumbuhan yang optimal, tanaman penghasil rimpang termasuk jahe memerlukan unsur hara yang cukup banyak khususnya $\mathrm{N}, \mathrm{P}$, dan $\mathrm{K}$. Nilai $\mathrm{R}=0,804$ menunjukkan arti bahwa setiap $80,4 \%$ penurunan P-tersedia akan diikuti oleh peningkatan produktivitas jahe dan sisanya dipengaruhi oleh faktor lain. Berdasarkan hasil penarikan garis batas, dapat ditentukan batas kelas P-tersedia antara kelas $\mathrm{N}$ dengan S3 adalah $>15,96$ ppm, untuk batas kelas S3 dengan S2 adalah 9,10 ppm, dan sedangkan batas kelas S2 dengan S1 tidak dapat diketahui karena tidak terdapat adanya sebaran data yang diperoleh.

\section{Hubungan antara KTK dengan produktivitas}

Berdasarkan hasil uji korelasi hubungan antara KTK dengan produktivitas jahe menunjukkan bahwa KTK memiliki keeratan yang kuat dengan produktivitas, nilai koefisien korelasi (r) yang didapat sebesar 0,676 . Hasil korelasi 
menunjukkan nilai yang positif, maka dapat diasumsikan bahwa setiap kenaikan KTK akan diikuti dengan meningkatnya produktivitas jahe. Hubungan linier pada persamaan $y=0,025 x+$ 1,995 memiliki arti bahwa setiap kenaikan 1 me $100 \mathrm{~g}^{-1} \mathrm{KTK}$ dapat meningkatkan produktivitas jahe sebesar $0,025 \mathrm{t} \mathrm{ha}^{-1}$. Nilai $\mathrm{R}^{2}=0,457$ menunjukkan bahwa setiap terjadi peningkatan produktivitas, KTK memberikan pengaruh sebesar $45,7 \%$ dan sisanya dipengaruhi oleh faktor lain. Musa et al. (2006) menjelaskan bahwa KTK merupakan kemampuan tanah dalam mengikat dan mempertukarkan kation, jika KTK tanah rendah maka kemampuan tanah dalam mengikat kation menjadi rendah. KTK selain berfungsi sebagai tempat jerapan jerapan kation-kation, juga berperan sebagai sumber pembebasan unsur hara yang kemudian dapat dimanfaatkan oleh tanaman untuk pertumbuhan dan perkembangannya (Tan, 1991). Berdasarkan hasil penarikan garis batas, dapat ditentukan batas kelas KTK antara kelas $\mathrm{N}$ dengan S3 adalah sebesar 17,8 (me $100 \mathrm{~g}^{-1}$ ), kelas S3 dengan S2 adalah 65,8 (me $100 \mathrm{~g}^{-1}$ ) dan kelas S2 dengan S1 adalah 113,9.

\section{Hubungan antara Ca-dd dengan produkivitas}

Berdasarkan hasil analisis uji korelasi antara Cadd dengan produktivitas jahe menunjukkan bahwa Ca-dd memiliki keeratan hubungan yang kuat dengan produktivitas, nilai koefisien korelasi (r) yang didapat sebesar 0,603. Hasil korelasi menunjukkan nilai yang positif, maka dapat diasumsikan bahwa setiap kenaikan Ca-dd akan diikuti dengan meningkatnya produktivitas jahe. Hubungan linier pada persamaan y = $0,079 x+2,350$ memiliki arti bahwa setiap kenaikan 1 me $100 \mathrm{~g}^{-1} \quad$ Ca-dd dapat meningkatkan produktivitas jahe sebesar $0,079 \mathrm{t}$ $\mathrm{ha}^{-1}$. Nilai $\mathrm{R}^{2}=0,333$ menunjukkan arti bahwa Ca-dd memberikan pengaruh sebesar 33,3\% terhadap peningkatan produktivitas dan sisanya dipengaruhi oleh faktor lain. Ca memiliki peran $\mathrm{Ca}$ dalam menentukan produktivitas. Hal ini juga didukung oleh pernyataan Budi dan Sari (2015) yang menyatakan bahwa Ca berperan dalam hidrolisis tepung menjadi gula sehingga ketersediaan unsur hara $\mathrm{Ca}$ berperan dalam menentukan kualitas produksi tanaman. Berdasarkan hasil penarikan batas, proyeksi perpotongan sekat produktivitas dengan Ca-dd menunjukkan bahwa batas kelas Ca-dd antara kelas $\mathrm{N}$ dengan S3 adalah sebesar 0,63 me 100 $\mathrm{g}^{-1}$, kelas S3 dengan S2 adalah 15,82 dan kelas S2 dengan S1 adalah 31,01.

\section{Karakteristik lahan yang paling berpengaruh terhadap produktivitas}

Potensi produktivitas tanaman jahe dipengaruhi oleh karakteristik lahan. Hasil analisis menunjukkan bahwa terdapat 4 karakteristik lahan yang paling berpengaruh terhadap produktivitas yaitu P-tersedia, C-organik, KTK, dan Ca-dd. Grafik hubungan antara produktivitas dengan parameter terkait disajikan pada Gambar 3. Karakteristik tersebut dihasilkan melalui uji regresi berganda (stepwise). Hasil uji regresi berganda (stepwise) memperoleh persamaan terbaik yaitu:

$\begin{aligned} \mathrm{Y}= & 3.292+(-0.219) \mathrm{X} 1+0.333 \mathrm{X} 2+0.335 \mathrm{X} 3 \\ & +0.348 \mathrm{X} 4\end{aligned}$

Keterangan:

$\begin{array}{lll}\mathrm{Y} & = & \text { Produktivitas } \\ \mathrm{X} 1 & = & \text { P-tersedia } \\ \mathrm{X} 2 & = & \text { C-organik } \\ \mathrm{X} 3 & = & \text { KTK } \\ \mathrm{X} 4 & = & \text { Ca-dd }\end{array}$

P-tersedia merupakan karakteristik lahan yang paling berpengaruh terhadap produktivitas jahe, kemudian diikuti oleh karakteristik yang lainnya yaitu C-organik, KTK dan Ca-dd. Hasil analisis menjelaskan melalui nilai koefisien determinasi $\left(\mathrm{R}^{2}\right)$ yang mempunyai nilai sebesar 0.695 atau sebesar 69,5\%. Karakteristik lahan tersebut mempunyai pengaruh sebesar $69,5 \%$ terhadap produktivitas jahe, sedangkan 30,5\% lainnya dipengaruhi oleh faktor yang lain.

\section{Kesimpulan}

Tingkat kelerengan tidak mempengaruhi terhadap produktivitas, daerah penelitian yang berada di Kecamatan Karangploso, Kecamatan Singosari, Kecamatan Jabung, Kecamatan Pagak dan Kecamatan Kalipare memiliki tingkat kelas kesesuaian lahan S3 (Sesuai Marginal). Faktor pembatas yang paling berpengaruh terhadap produksi jahe adalah kelerengan (eh) sebesar 16$23 \%$, curah hujan (wa) sebesar 1.415 hingga $1794 \mathrm{~mm}$ selama musim tanam, dan retensi hara 
(nr) pH sebesar 4,12 hingga 5,12 \& Kejenuhan Basa sebesar 16 hingga 33\%. Kelas kesesuaian
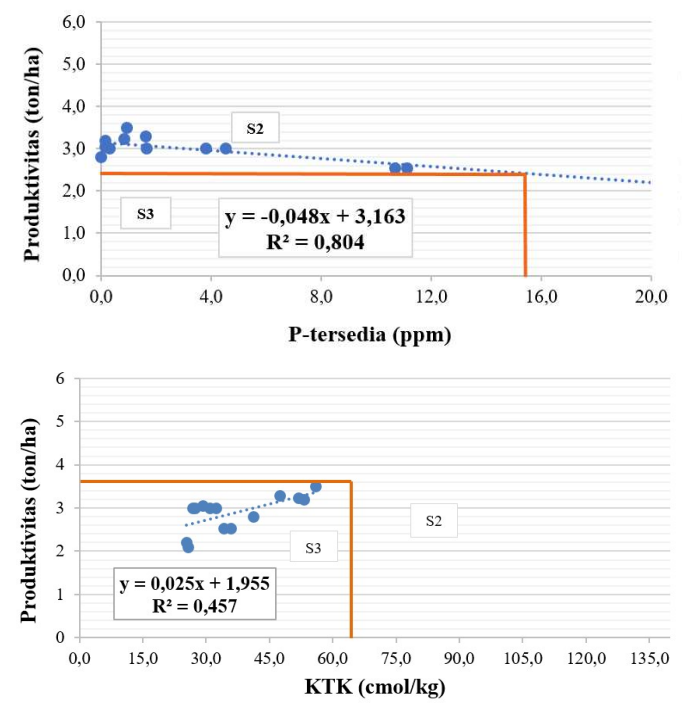

lahan memiliki hubungan yang kuat dengan produktivitas aktual tanaman jahe.
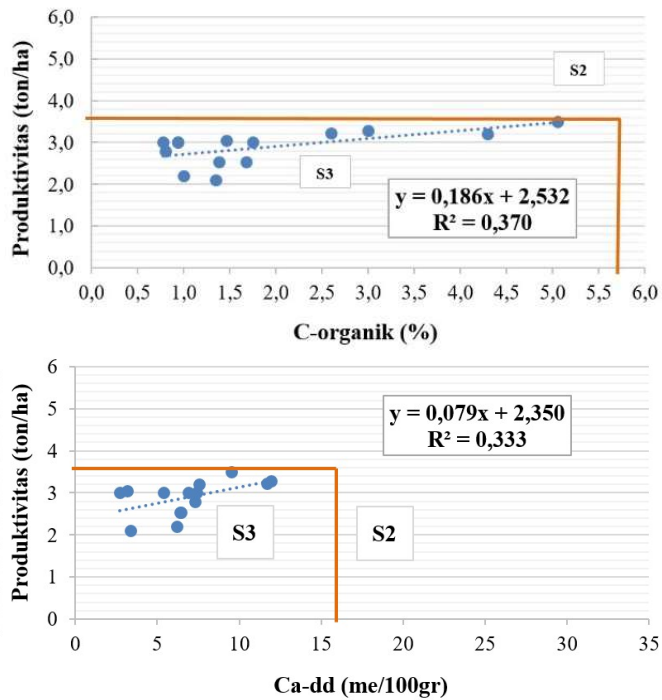

Gambar 3. Grafik hubungan antara produktivitas dengan parameter terkait.

\section{Daftar Pustaka}

Badan Pusat Statistik. 2016. Tabel Dinamis 2016, Oktober 27. https://www.bps.go.do/site/resulttab. Diunduh pada tanggal 14 Juli 2018.

Badan Pusat Statistik. 2017. Produksi Tanaman Obat Rimpang di Indonesia 20122016.http://pangan.litbang.pertanian.go.id//Sta tistik/StatistikPertanian2017. pdf, diakses tanggal 25 Januari 2018.

Budi, S. dan Sari, S. 2015. Ilmu dan Implementasi Kesuburan Tanah. UMMPRESS. Malang. Pp 54140.

Direktorat Jendral Perkebunan. 2004. Satatistik Perkebunan: Jahe. Direktorat Jendral Perkebunan. Jakarta. 50 hal.

Djaenudin D, Marwan H, Subagyo H, dan Hidayat A. 2011. Petunjuk Teknis Evaluasi Lahan Untuk Komoditas Pertanian. Balai Besar Litbang Sumberdaya Lahan Pertanian, Badan Litbang Pertanian, Bogor. 36p.
Food and Agriculture Organization. 1976. A Frame Work for Land Evaluation [Soil Buletin]. Food and Agriculture Organization of the United Nations. Rome. Italy.

Musa, L., Mukhlis, dan A. Rauf. 2006. Dasar-Dasar Ilmu Tanah. Universitas Sumatera Utara. Medan.

Rosita, S.M.D., M. Rahardjo dan Kosashi. 2009. Pola Pertumbuhan dan Serapan N, P, dan K Tanaman Bangle (Zingiber purpurium Roxb.) Jurnal Littri. 1(1): 32-36.

Rostiana, O. Nurliani B dan R. Mono. 2005. Budidaya Tanaman Jahe. Badan Penelitian dan Pengembangan Pertanian, Balai Penelitian Tanaman Obat dan Aromatika. Sirkuler No. 11.

Susanto, A.N. 2005. Pemetaan Dan Pengelolaan Status Kesuburan Tanah Di Dataran Wai Apu, Pulau Buru. Jurnal Pengkajian dan Pengembangan Teknologi Pertanian Vol. 8, No.3, Nopember 2005, P : 315-332.

Tan, K. H. 1991. Dasar - Dasar Kimia Tanah. UGM Press. Yogyakarta. Terjemahan: D. H. Goenadi. 259 Hal. 
halaman ini sengaja dikosongkan 